\title{
Zaposlovanje javnih uslužbencev
}

\author{
UDK: 35(497.4):331.5
}

\author{
Tatjana Kozjek \\ Univerza v Ljubljani, Fakulteta za upravo \\ tatjana.kozjeke@fu.uni-lj.si
}

\begin{abstract}
IZVLEČEK
Javni uslužbenci so posamezniki, ki sklenejo delovno razmerje $v$ javnem sektorju. Zakon loči uradnike od drugih javnih uslužbencev. Ta ločitev pa je tudi vzrok za razlike, ki nastajajo $v$ postopkih zaposlovanja. Za zaposlene $v$ javnem sektorju veljajo določene posebnosti pri zaposlovanju zaradi narave njihovega dela. S svojim delom uresničujejo javni interes in uporabljajo javna sredstva, ki se lahko uporabljajo samo za namene, določene v predpisih. Prispevek prikazuje postopek zaposlovanja javnih uslužbencev ter nekatere razlike in posebnosti pri njihovem zaposlovanju.
\end{abstract}

Ključne besede: zaposlovanje, javni uslužbenec, strokovno-tehnično delovno mesto, uradniško delovno mesto, položaj.

\section{Uvod}

Zakon o javnih uslužbencih (1. in 23. člen) definira javne uslužbence kot posameznike, ki sklenejo delovno razmerje $v$ javnem sektorju, pri čemer loči uradnike od drugih javnih uslužbencev, strokovno-tehničnih javnih uslužbencev. Funkcionarji v državnih organih in upravah lokalnih skupnosti (ministri, predstojniki vladnih služb in organov v sestavi ter župani) niso javni uslužbenci.

Razvoj upravnih sistemov $v$ zadnjih dvajsetih letih je vplival tudi na zaposlitveni režim $\vee$ javni upravi. Zaradi krčenja področij, kjer je potrebna intervencijska vloga države, in umika države s posameznih področij s procesi privatizacije in deregulacije, je prišlo do izločitve velikega števila zaposlenih $v$ javni upravi iz javnopravnega režima $\vee$ zasebnopravni režim. Tudi uvajanje prilagojenih menedžerskih metod in tehnik, značilnih za zasebni sektor, v sistem upravljanja javnega sektorja, je vplivalo na zaposlitveni režim v javni upravi: to je na sistem plač, na uvajanje fleksibilnejših oblik zaposlovanja, na strukturo delavskega 


\section{Tatjana Kozjek}

\section{Zaposlovanje javnih uslužbencev}

predstavništva in kolektivnega dogovarjanja, na decentralizacijo, ipd. (Ministrstvo za javno upravo, 2008).

Za zaposlene $\vee$ javnem sektorju veljajo določene posebnosti pri zaposlovanju zaradi narave njihovega dela. S svojim delom uresničujejo javni interes in uporabljajo javna sredstva, ki se lahko uporabljajo samo za namene, določene $v$ predpisih. Postopki zaposlovanja so zato zahtevno in odgovorno opravilo, pri katerem je treba upoštevati postopkovne zahteve in zadovoljiti interes za pridobitev dobrega, uspešnega ter najbolj strokovno usposobljenega kandidata (po načelu enakopravne dostopnosti), nove zaposlitve se morajo izvajati tudi v skladu s predpisi in predvidene morajo biti v kadrovskih načrtih.

\section{Pojmovne opredelitve}

$\checkmark$ nadaljevanju so navedene opredelitve pojmov, ki so uporabljeni $v$ prispevku.

Javni uslužbenec je posameznik, ki sklene delovno razmerje $\vee$ javnem sektorju (ZJU, 1. člen). Funkcionarji v državnih organih in organih lokalnih skupnosti niso javni uslužbenci (Brejc, 2002, str. 35).

Strokovno-tehniško delovno mesto je delovno mesto, na katerem se izvajajo naloge, ki sicer sodijo $v$ delovno področje državnega organa ali organa lokalne skupnosti oziroma naloge, za katere je bila ustanovljena oseba javnega prava, vendar pa po svoji vsebini predstavljajo strokovno-tehnične naloge (Uredba o notranji organizaciji, sistemizaciji, delovnih mestih in nazivih javne uprave in pravosodnih organih, 54. člen).

Uradniško delovno mesto je tisto delovno mesto, na katerem se opravljajo javne naloge, in delovna mesta vodij finančne, računovodske, kadrovske, pravne službe in službe za informatiko, glavne pisarne in službe za stike z javnostmi. Sem sodijo tudi delovna mesta javnih uslužbencev, na katerih se opravljajo zahtevnejša spremljajoča dela, ki so bistvenega pomena za izvrševanje nalog organa in za opravljanje katerih je zahtevano poznavanje javnih nalog organa ter najmanj visoka strokovna izobrazba (Uredba o notranji organizaciji, sistemizaciji, delovnih mestih in nazivih javne uprave in pravosodnih organih, 51. člen).

Položaj je uradniško delovno mesto, na katerem se opravljajo naloge vodenja, ki vsebujejo vodstvene naloge (načrtovanje, organiziranje, usmerjanje 
in nadzor) in najzahtevnejše strokovne naloge ali naloge nadomeščanja in neposredne pomoči uradnikom na položajih generalnega direktorja in generalnega sekretarja $\vee$ ministrstvih, direktorja organa $\vee$ sestavi in direktorja vladne službe (namestniki) (ZJU; 80. člen).

\section{Javni uslužbenski sistem}

Zakon o javnih uslužbencih (7.-32. člen) ureja javni uslužbenski sistem, to so skupna načela in druga skupna vprašanja sistema javnih uslužbencev, razen sistema plač v javnem sektorju.

$\checkmark$ prvem delu so navedene skupne osnove sistema javnih uslužbencev, ki veljajo za vse zaposlene $v$ javnem sektorju, drugi del pa velja le za javne uslužbence v državnih organih in upravah lokalnih skupnosti (Brejc, 2002, str. 35).

Med skupna načela sistema javnih uslužbencev sodijo: načela enakopravne dostopnosti, zakonitosti, strokovnosti, častnega ravnanja, omejitve dolžnosti $\vee$ zvezi s sprejemanjem daril, zaupnosti, odgovornosti za rezultate, dobrega gospodarja ter varovanja poklicnih interesov (ZJU, 7.-15. člen).

$\checkmark$ državnih organih in upravah lokalnih skupnosti pa morajo javni uslužbenci upoštevati še naslednja načela: načela javnega natečaja, politične nevtralnosti in nepristranskosti, kariere, prehodnosti, varovanja poklicnih interesov, odprtosti do javnosti (ZJU, 27.-32. člen).

Vsebina prispevka se omejuje na zaposlovanje javnih uslužbencev, zato bodo $v$ nadaljevanju podrobneje predstavljena le naslednja načela: načelo enakopravne dostopnosti, načelo javnega natečaja, načelo kariere in načelo prehodnosti.

Zakon o javnih uslužbencih $\vee 7$. členu opredeljuje načelo enakopravne dostopnosti. $\vee$ omenjenem načelu je določeno, da se zaposlovanje javnih uslužbencev izvaja tako, da je zagotovljena enakopravna dostopnost delovnih mest za vse zainteresirane kandidate pod enakimi pogoji in tako, da je zagotovljena izbira kandidata, ki je najbolje strokovno usposobljen za opravljanje nalog na delovnem mestu.

V 27. členu ZJU je opredeljeno načelo javnega natečaja, ki določa, da se uradniki izbirajo na javnem natečaju, razen $v$ primerih, ko je z zakonom drugače določeno. $\vee$ postopku javnega natečaja se kandidati obravnavajo enakopravno, izbira pa se opravi na podlagi izkazane najboljše strokovne usposobljenosti. 


\section{Tatjana Kozjek}

\section{Zaposlovanje javnih uslužbencev}

Načelo kariere navaja, da je uradniku omogočena kariera z napredovanjem. Kariera je odvisna od strokovne usposobljenosti in drugih delovnih in strokovnih kvalitet ter od rezultatov dela (29. člen ZJU).

Po načelu prehodnosti je javni uslužbenec lahko premeščen na drugo delovno mesto $v$ okviru organov (30. člen ZJU).

Korpič-Horvatova (2008, str. 1) navaja, da varovanje javnega interesa zahteva večje omejitve avtonomije pogodbenih strank, javnega uslužbenca in delodajalca pri urejanju uslužbenskih razmerij kot $v$ zasebnem. Za zaposlene $v$ zasebnem sektorju se namreč opredeljuje načelo in favorem laboratoris. Načelo opredeljuje, da se s pogodbo o zaposlitvi oziroma s kolektivno pogodbo lahko določijo pravice, ki so za delavce ugodnejše, kot jih določa Zakon o delovnih razmerjih.

Zakon o javnih uslužbencih (16. člen) navaja, da delodajalec javnemu uslužbencu ne sme zagotavljati pravic $v$ večjem obsegu, kot je to določeno z zakonom, podzakonskim predpisom ali s kolektivno pogodbo, če bi $s$ tem obremenil javna sredstva. Predstojnik prav tako ne sme sprejeti odločitve in javnemu uslužbencu določiti večje ali manjše pravice oziroma manj ali bolj ugodne pogoje dela kot določajo predpisi delovnega prava in kolektivne pogodbe (92. člen ZJU).

\section{Postopek zaposlovanja javnih uslužbencev}

Delodajalec je pravna oseba, $s$ katero je javni uslužbenec $v$ delovnem razmerju. $\vee$ državnem organu je to Republika Slovenija, $v$ upravi lokalne skupnosti pa lokalna skupnost. $\vee$ imenu delodajalca nastopa predstojnik, ki so mu zaupane naloge $v$ zvezi z odločanjem o zaposlovanju in drugih zadevah upravljanja s človeškimi viri. Kadrovsko odločanje je torej v domeni upravnih menedžerjev, funkcionarjem pa so pridržane odločitve splošnega pomena, npr. določanje skupnih izhodišč za sistemizacijo (Korade Purg, 2008, str. 31).

Zakon o javnih uslužbencih (16. člen) določa, da se pravice in obveznosti javnih uslužbencev iz delovnih razmerij urejajo s predpisi s področja delovnih razmerij, s kolektivnimi pogodbami, s zakonom tem in z drugimi zakoni ter $\mathrm{s}$ podzakonskimi predpisi, izdanimi na njihovi podlagi .

Posebnosti delovnih razmerij javnih uslužbencev ureja Zakon o javnih uslužbencih, torej tistih, ki imajo sklenjeno delovno razmerje $v$ javnem sektorju, pri čemer seveda glede delovnih razmerij, pravic in dolžnosti javnih uslužbencev 
veljajo tudi predpisi, ki urejajo delovna razmerja, pa tudi kolektivne pogodbe. To torej pomeni, da velja splošno delovno pravo za vsa vprašanja, ki jih zakon o javnih uslužbencih ali drug področni zakon ne urejata drugače. $V$ zvezi z delovnim razmerjem javnega uslužbenca je treba opozoriti še na dejstvo, da je na drugi strani pogodbena stranka država ali občina, saj se večina zakona uporablja za javne uslužbence $v$ državnih organih in upravah lokalnih skupnosti. To dejstvo je pomembno zaradi tega, ker gre $\vee$ obeh primerih za pravni osebi, ki izvajata oblast (Korade Purg, 2008, str. 31).

$\checkmark$ 56. členu ZJU je določeno, da o zaposlitvah odloča predstojnik. Odločitev o zaposlitvi se sprejme, če so izpolnjeni naslednji pogoji: da se trajno ali začasno poveča obseg dela, povečanega obsega dela pa ni mogoče opravljati z obstoječim številom javnih uslužbencev, oziroma se ob nespremenjenem obsegu dela izprazni delovno mesto; da ima organ zagotovljena finančna sredstva za zaposlitev; da je delovno mesto določeno $v$ sistemizaciji (razen izjem, določenih $\vee$ 55. členu ZJU); da je delovno mesto prosto; da je nova zaposlitev $v$ skladu s kadrovskim načrtom.

Nove zaposlitve javnih uslužbencev so opredeljene v kadrovskem načrtu. Zakon o javnih uslužbencih $v$ 42. členu navaja, da se $s$ kadrovskim načrtom prikaže dejansko stanje zaposlenosti po delovnih mestih ter $v$ skladu z delovnim področjem in delovnim programom organa za obdobje dveh let določi predvideno ciljno stanje zaposlenosti po delovnih mestih, za katera se sklene delovno razmerje za nedoločen čas, ter predvidene zaposlitve za določen čas.

$\checkmark$ kadrovskem načrtu se prikaže tudi predvideno zmanjšanje števila delovnih mest ali prestrukturiranje delovnih mest, določi se tudi najvišje možno število pripravnikov, vajencev, dijakov in študentov na praktičnem pouku ali na podobnem teoretičnem in praktičnem usposabljanju. Načrtovanje novih zaposlitev za nedoločen čas in načrtovanje novih zaposlitev za določen čas je mogoče, če se trajno ali začasno poveča obseg dela, povečanega obsega dela pa ni mogoče opravljati z obstoječim številom javnih uslužbencev (ZJU, 42. člen).

Preden sprejme odločitev o novi zaposlitvi, predstojnik preveri, ali je mogoče prosto delovno mesto zasesti s premestitvijo javnega uslužbenca iz istega organa. Če prostega delovnega mesta ni mogoče zasesti na tak način, se lahko delovno mesto zasede s premestitvijo javnega uslužbenca iz drugega organa; za ta namen se lahko izvede interni natečaj (57. člen, ZJU).

Delovno razmerje sklene javni uslužbenec $s$ pogodbo o zaposlitvi za delovno mesto, ki je določeno $v$ sistemizaciji. Delovno razmerje se lahko sklene tudi za delovno mesto, ki ni sistemizirano, vendar se to lahko sklene le za 
Tatjana Kozjek

Zaposlovanje javnih uslužbencev

določen čas ali za opravljanje pripravništva (55. člen, ZJU). Vodovnik (2004, str. 128) navaja, da javni uslužbenec vstopi $\vee$ delovno razmerje s sklenitvijo pogodbe o zaposlitvi.

Pogodba o zaposlitvi mora vsebovati naslednje sestavine (54. člen ZJU): navedbo pogodbenih strank; navedbo organa, $v$ katerem bo javni uslužbenec opravljal delo; čas trajanja delovnega razmerja; navedbo delovnega mesta oziroma položaja, na katerem bo javni uslužbenec opravljal delo, oziroma podatke o vrsti dela s kratkim opisom dela; datum začetka opravljanja dela; kraj opravljanja dela; določilo o tem, ali se delo opravlja s polnim ali skrajšanim delovnim časom; druge podatke, ki jih določa ta zakon ali področni zakon, ki ureja položaj javnih uslužbencev $\vee$ organih; določilo o osnovni plači in morebitnih dodatkih, vezanih na delovno mesto; določilo o letnem dopustu; določilo o delovnem času; določilo o odpovednem roku; navedbo, da lahko posamezne sestavine pogodbe delodajalec enostransko spreminja v skladu z zakonom.

45. člen Uredbe o notranji organizaciji, sistemizaciji, delovnih mestih in nazivih $v$ organih javne uprave in pravosodnih organih določa, da na posameznem delovnem mestu dela ne more opravljati več kot en javni uslužbenec s polnim delovnim časom. Izjemoma lahko, na primer za potrebe uvajanja $v$ delo, na istem delovnem mestu dva javna uslužbenca delata največ en mesec. V Ministrstvu za zunanje zadeve $\vee$ času priprav za delo $v$ zunanji službi na istem delovnem mestu lahko dva javna uslužbenca delata največ tri mesece, medtem ko $\vee$ Ministrstvu za obrambo, $v$ času priprav za delo $v$ tujini, dva javna uslužbenca delata največ šest mesecev. Izjema $v$ teh dveh primerih je dovoljena le $\vee$ primeru, kadar gre za premestitve javnih uslužbencev znotraj organa državne uprave, ne pa $\vee$ primeru sklenitve novega delovnega razmerja. $V$ primerih, ko pripravnikom Slovenske vojske preneha veljati pogodba o zaposlitvi brez krivdnih razlogov, lahko $\vee$ Ministrstvu za obrambo $v$ času priprav delo opravljata dva pripravnika, vendar ne več kot šest mesecev.

Zakon o javnih uslužbencih loči uradniška in strokovno-tehniška delovna mesta, ta ločitev pa pride do izraza še posebej v postopku izbire kandidata in sklenitve delovnega razmerja za prosto delovno mesto.

\subsection{Posebnosti zaposlovanja na strokovno-tehniška delovna mesta}

51. člen Uredbe o notranji organizaciji, sistemizaciji, delovnih mestih in nazivih $\vee$ organih javne uprave in pravosodnih organih za strokovno-tehnična 
delovna mesta navaja, da so to delovna mesta, na katerih se izvajajo naloge, ki sicer sodijo $v$ delovno področje državnega organa ali organa lokalne skupnosti oziroma naloge, za katere je bila ustanovljena oseba javnega prava, vendar pa po svoji vsebini predstavljajo strokovno-tehnične naloge (druga spremljajoča dela), ne pa uradniških nalog. 23. člen Zakona o javnih uslužbencih navaja, da so spremljajoča dela: dela na področju kadrovskega in materialno-finančnega poslovanja, tehnična in podobna dela ter druga dela, ki jih je treba opravljati zaradi nemotenega izvajanja javnih nalog organa.

Strokovno-tehniška delovna mesta razvrsti za vse organe vlada z uredbo. Lahko pa se razvrstijo še s kolektivno pogodbo. Strokovno-tehnična delovna mesta so razvrščena: glede na poimenovanje strokovno-tehničnega delovnega mesta, navedbo nalog, ki se opravljajo na posameznem strokovno-tehničnem delovnem mestu, glede na zahtevano število delovnih izkušenj in zahtevano stopnjo strokovne izobrazbe, ki se določi z navedbo tarifnega razreda. Za zasedbo posameznega strokovno-tehničnega delovnega mesta so določeni splošni pogoji, ki jih urejajo predpisi s področja delovnega prava, stopnja in smer izobrazbe oziroma poklicna kvalifikacija in delovne izkušnje (Uredba o notranji organizaciji, sistemizaciji, delovnih mestih in nazivih $\vee$ organih javne uprave in pravosodnih organih, 51. člen).

Postopek za novo zaposlitev na strokovno-tehničnem delovnem mestu se izvaja po postopku, določenem s predpisi, ki urejajo delovna razmerja in kolektivno pogodbo (Koželj, 2004, str. 30).

Zakon o delovnih razmerjih določa, da se delovno razmerje sklene s pogodbo o zaposlitvi, pri čemer velja pogodbena svoboda. To pomeni, da ima delodajalec pravico do odločitve, s katerim kandidatom bo sklenil delovno razmerje oziroma pogodbo o zaposlitvi, seveda ob upoštevanju zakonskih prepovedi glede diskriminacije in ob upoštevanju obveznosti glede izpolnjevanja zahtevanih pogojev za opravljanje dela. Obveznost glede izpolnjevanja zahtevanih pogojev, ki je prisotna pri sklenitvi pogodbe o zaposlitvi, je obojestranska in veže tako delodajalca kot delavca. Pomeni namreč, da mora delavec, ki želi skleniti pogodbo o zaposlitvi, izpolnjevati zahtevane pogoje, delodajalec pa mora skleniti delovno razmerje samo s tistim delavcem, ki izpolnjuje te pogoje. Pogoje za opravljanje dela lahko določa zakon, kolektivna pogodba ali pa jih določi delodajalec sam s svojim splošnim aktom. Pomembno je še, da morajo biti prosta delovna mesta in pogoji za opravljanje dela na teh delovnih mestih javno objavljeni, hkrati pa mora biti določen tudi rok za prijavo, ki ne sme biti krajši od petih dni (Korade Purg, 2008, str. 28-31). 


\section{Tatjana Kozjek}

\section{Zaposlovanje javnih uslužbencev}

Prosto delovno mesto je treba objaviti, nato pa se izmed prijavljenih kandidatov, katerih prijava je prispela pravočasno in ki izpolnjujejo razpisne pogoje, izbere z izbirnim postopkom najustreznejšega kandidata. Pred sklenitvijo delovnega razmerja pa se lahko opravi tudi preizkus usposobljenosti (ZJU, 67. člen).

Javna objava je objava $v$ sredstvih javnega obveščanja, kjer začne teči rok za prijavo naslednji dan po objavi, in objava $\vee$ uradnih prostorih Zavoda Republike Slovenije za zaposlovanje. Pomembno je tudi, da mora delodajalec, ki ima zaposlene delavce za določen čas, $v$ primerih, ko želi zaposlovati za nedoločen čas na prosta delovna mesta, o tem obvestiti tudi že zaposlene, in sicer z objavo na pri delodajalcu običajen način. S tem daje možnost predvsem tistim, ki imajo sklenjeno delovno razmerje za določen čas, da ob izpolnjevanju pogojev kandidirajo za zaposlitev za nedoločen čas (Korade Purg, 2008, str. 29).

Uredba o postopku za zasedbo delovnega mesta $\vee$ organih državne uprave in pravosodnih organih (10. člen) pravi, da ni treba navajati dokazil o izpolnjevanju pogojev za opravljanje dela, ki bi jih moral kandidat prilagati prijavi, ter da se navaja tudi elektronski naslov za vlaganje prijav, glede na to, da je možna tudi samo elektronska prijava kandidata. Uredba zahteva tudi, da organi podatkov o dejstvih, ki se vodijo $v$ uradnih evidencah državnih organov, organov samoupravne lokalne skupnosti ali pri nosilcih javnega pooblastila, ne zahtevajo od kandidatov, temveč jih pridobijo sami. Podatki iz uradnih evidenc pa se pridobijo le za izbranega kandidata, pred odločitvijo o izbiri.

Za strokovno-tehnična delovna mesta se kot pogoji za opravljanje dela poleg splošnih pogojev, ki jih urejajo predpisi s področja delovnega prava, določijo stopnja in smer izobrazbe ter delovne izkušnje, lahko pa tudi znanje uradnega jezika, funkcionalna in specialna znanja ter posebne sposobnosti ali drugi pogoji, če tako določa zakon (ZJU, 79. člen).

52. člen Uredbe o notranji organizaciji, sistemizaciji, delovnih mestih in nazivih $v$ organih javne uprave in pravosodnih organih določa, da se kot pogoji za zasedbo strokovno-tehničnega delovnega mesta navajajo: splošni pogoji $v$ skladu s predpisi s področja delovnega prava, stopnja in smer izobrazbe oziroma poklicna kvalifikacija, delovne izkušnje, aktivno znanje uradnega jezika, funkcionalna in specialna znanja, posebne sposobnosti in drugi pogoji (glede na vsebino nalog).

Pred sklenitvijo delovnega razmerja za strokovno-tehnična delovna mesta se lahko opravi predhodni preizkus usposobljenosti. Predstojnik lahko odloči, da se delovno razmerje sklene pod pogojem, da javni uslužbenec uspešno opravi poskusno delo, razen $\vee$ primeru, ko je javni uslužbenec predhodno že opravil 
preizkus usposobljenosti. Poskusno delo lahko traja največ šest mesecev. V primeru neuspešno opravljenega poskusnega dela se uporabljajo določbe tega zakona o posledicah ugotovitve nesposobnosti (ZJU, 67. člen).

\subsection{Posebnosti zaposlovanja na uradniška delovna mesta}

51. člen Uredbe o notranji organizaciji, sistemizaciji, delovnih mestih in nazivih $\vee$ organih javne uprave in pravosodnih organih določa, da so uradniška delovna mesta tista, na katerih se opravljajo javne naloge, in delovna mesta vodij finančne, računovodske, kadrovske, pravne službe in službe za informatiko, glavne pisarne in službe za stike z javnostmi. Sem sodijo tudi delovna mesta javnih uslužbencev, na katerih se opravljajo zahtevnejša spremljajoča dela, ki so bistvenega pomena za izvrševanje nalog organa in za opravljanje katerih je zahtevano poznavanje javnih nalog organa ter najmanj visoka strokovna izobrazba. Ne glede na zahtevano stopnjo izobrazbe med uradniška delovna mesta mednje sodijo tudi delovna mesta $\vee$ Slovenski obveščevalnovarnostni agenciji, Obveščevalno varnostni službi Ministrstva za obrambo in Policiji, delovna mesta na katerih se opravljajo spremljajoča dela, ki so neposredno operativno povezana $s$ policijskimi in obveščevalno-varnostnimi nalogami.

78. člen Zakona o javnih uslužbencih pravi, da uradniška delovna mesta v organih državne uprave, pravosodnih organih in upravah lokalnih skupnosti razvrsti vlada z uredbo. Drugi organi uredijo to vprašanje s svojim splošnim aktom. Uradniška delovna mesta se lahko razvrstijo s kolektivno pogodbo.

Za zaposlitev na uradniškem delovnem mestu veljajo pravila javnega natečaja, kar posebej določa Zakon o javnih uslužbencih, upoštevaje tudi 122. člen Ustave Republike Slovenije. Ta določa, da je zaposlitev v upravnih službah mogoča samo na podlagi javnega natečaja, razen $\vee$ primerih, ki jih določa zakon. Gre za postopek, natančno določen z zakonom o javnih uslužbencih, ki mora zagotoviti izbiro najprimernejšega kandidata, pri čemer je kot merilo primernosti upoštevana njegova strokovna usposobljenost, ki bo omogočila učinkovito in uspešno opravljanje dela (Korade Purg, 2008, str. 28).

Uradniki, ki opravljajo javne naloge, se praviloma izbirajo na javnem natečaju. Delodajalec mora ob sklepanju delovnega razmerja za uradniška delovna mesta upoštevati načelo javnega natečaja, ki določa, da se uradniki izbirajo na javnem natečaju, s katerim je omogočeno vsem prijavljenim kandidatom 


\section{Tatjana Kozjek}

\section{Zaposlovanje javnih uslužbencev}

enakopravno obravnavanje. Odločilni kriterij za izbiro kandidata je boljša strokovna usposobljenost (Vodovnik, 2004, str. 126).

Javni natečaj mora biti obvezno javno objavljen in sicer: za organe državne uprave na spletni strani ministrstva, pristojnega za upravo; za druge državne organe in lokalne skupnosti na njihovih spletnih straneh. Javni natečaj se lahko objavi tudi $\vee$ Uradnem listu RS ali $\vee$ dnevnem časopisju, potrebna pa je tudi prijava prostega delovnega mesta pri Zavodu za zaposlovanje (Korade Purg, 2008, str. 32).

Besedilo javnega natečaja je sestavljeno iz dveh delov. Prvi del sestavljajo natečajni pogoji, ki jih mora kandidat izpolnjevati, da se uvrsti $\vee$ posebni izbirni postopek. Podlaga za določitev natečajnih pogojev je sistemizacija delovnih mest ter $\vee$ njej določeni pogoji za posamezen položaj, pri čemer so bile upoštevane določbe Zakona o javnih uslužbencih in Uredbe o notranji organizaciji, sistemizaciji delovnih mest in nazivov $v$ organe javne uprave in pravosodnih organih. Prav tako besedilo natečaja določa, katera dokazila je treba priložiti k prijavi z življenjepisom. Drugi del besedila vsebuje standarde strokovne usposobljenosti, kjer so povzete izkušnje, znanja, veščine in sposobnosti, ki jih mora imeti kandidat za posamezen položaj (Korade Purg, 2004, str. 27).

Zakon o javnih uslužbencih (59. člen) in Uredba o postopku za zasedbo delovnega mesta $\vee$ organih državne uprave in $v$ pravosodnih organih (19. člen) določata vsebino posamezne objave, in sicer mora objava javnega natečaja vsebovati podatke o: organu in kraju opravljanja dela, vrsti uradniškega delovnega mesta, pogojih za opravljanje dela, dokazilih, ki jih mora kandidat priložiti prijavi, roku in naslovu za vlaganje prijav, roku obveščanja o izbiri, osebi, ki daje informacije o izvedbi javnega natečaja in o okvirni vsebini dela.

52. člen Uredbe o notranji organizaciji, sistemizaciji, delovnih mestih in nazivih $v$ organih javne uprave in pravosodnih organih določa, da se kot pogoji za zasedbo uradniškega delovnega mesta navedejo: splošni pogoji $\vee$ skladu $s$ predpisi s področja delovnega prava, uradniški nazivi, smer izobrazbe, funkcionalna, specialna znanja in posebne sposobnosti. Izjemoma pa se določijo tudi posebni pogoji določeni s področnimi predpisi, $v$ primeru, da področni zakon za posamezna uradniška delovna mesta zahteva določeno stopnjo izobrazbe.

Sestavine objave internega ali javnega natečaja so enake, bistveno se razlikujejo predvsem $v$ delu, kjer je opredeljeno, kaj mora prijava vsebovati, saj se $v$ internih natečajih ne preverjajo ponovno pogoji, potrebni za imenovanje $v$ naziv, ki ga je ta pridobil že prej (na primer: državljanstvo). Se pa lahko kljub 
temu, da uradnik že ima določen naziv, še vedno na internem natečaju preverja, ali kandidat izpolnjuje pogoj, specifičen za to delovno mesto, denimo izobrazba, če se zahteva izključno pravna smer izobrazbe (Ramšak Pešec, 2007, str. 12).

Pravilo javnega natečaja velja tudi za že zaposlene javne uslužbence, ki še nimajo uradniškega naziva, oziroma imajo nižji naziv, kot se zahteva na delovnem mestu za katerega želijo kandidirati, kot tudi za vse tiste, ki želijo od zunaj vstopiti $\vee$ sistem in pričeti opravljati delo na uradniškem delovnem mestu (Korade Purg, 2008, str. 32).

\subsection{Posebnosti zaposlovanja uradnikov na položaju}

80. člen Zakona o javnih uslužbencih navaja, da je položaj uradniško delovno mesto, na katerem se opravljajo naloge vodenja, ki vsebujejo vodstvene naloge (načrtovanje, organiziranje, usmerjanje in nadzor) in najzahtevnejše strokovne naloge ali naloge nadomeščanja in neposredne pomoči uradnikom na položajih generalnega direktorja in generalnega sekretarja $\vee$ ministrstvih, direktorja organa $v$ sestavi in direktorja vladne službe (namestniki).

Položajna delovna mesta so tako $v$ ministrstvih: generalni direktor, generalni sekretar in vodje organizacijskih enot; $v$ organih $v$ sestavi ministrstva: direktor in vodje organizacijskih enot; $v$ upravnih enotah: načelnik upravne enote in vodje organizacijskih enot; $v$ vladnih službah: direktor in vodje organizacijskih enot; $\vee$ upravah lokalnih skupnosti: direktor in vodje organizacijskih enot (ZJU, 80. člen).

Zakon o javnih uslužbencih vzpostavlja poseben režim za najvišje vodstvene položaje $v$ državni upravi. Posebno vlogo ima pri tem Uradniški svet, ki določa standarde strokovne usposobljenosti, ki jih bodo morali dosegati kandidati, in merila za izbiro. Ti standardi in merila bodo izhodišča za imenovanje natečajnih komisij in določanje metod izbire, kar je tudi $\vee$ rokah uradniškega sveta (Virant, 2003, str. 20).

Zakon predvideva ustanovitev uradniškega sveta predvsem zaradi zagotavljanja najvišje stopnje strokovnosti in neodvisnosti uradnikov na najvišjih položajih ter za dajanje mnenj državnemu zboru in vladi o predpisih, ki urejajo uradniški sistem in položaj uradnikov (Sajevec Plavčak, 2003, str. 22).

Poslovnik uradniškega sveta (19., 20. člen) določa, da v postopku izbire uradnika na položaju uradniški svet imenuje posebno natečajno komisijo, katere člani so lahko le člani uradniškega sveta, pri čemer funkcionar, ki mu je uradnik 


\section{Tatjana Kozjek}

\section{Zaposlovanje javnih uslužbencev}

na položaju odgovoren, ne more biti član natečajne komisije. Imenovani so lahko tudi uradniki iz organov državne uprave in strokovnjaki s področja javne uprave, upravljanja kadrovskih virov in s področja, na katerem bo uradnik na položaju upravljal vodstvene naloge.

Posebna natečajna komisija ugotovi, kateri kandidati izpolnjujejo pogoje za položaj in kateri kandidati so glede na svojo strokovno usposobljenost primerni za ta položaj. Pri tem je dolžna upoštevati standarde strokovne usposobljenosti, merila za izbiro in metode za preverjanje usposobljenosti, ki jih je določil uradniški svet. Kandidatu, ki je uvrščen na seznam tistih kandidatov, ki izpolnjujejo pogoje in so glede na strokovno usposobljenost primerni za položaj, kakor tudi kandidatom, ki se niso uvrstili na navedeni seznam, izda posebna natečajna komisija sklep. Seznam kandidatov, ki so primerni za položaj, odda komisija pristojnemu funkcionarju. $\vee$ primeru, da pristojni funkcionar oceni, da noben izmed kandidatov s seznama, ki mu ga je predložila posebna natečajna komisija, ni primeren za položaj, lahko zahteva od uradniškega sveta, da postopek ponovi. Uradniški svet $v$ tem primeru lahko imenuje novo posebno natečajno komisijo (Poslovnik Uradniškega sveta, 20. člen).

Poslovnik Uradniškega sveta $\vee$ 18. členu določa naslednje naloge uradniškega sveta: skrbi za izvajanje izbire uradnikov na položajih; določa standarde strokovne usposobljenosti, merila za izbiro in metod preverjanja usposobljenosti kandidatov za zasedbo položajev; daje mnenja vladi in državnemu zboru o predpisih, ki urejajo uradniški sistem in položaj uradnikov; $\vee$ sodelovanju z reprezentativnimi sindikati $v$ organu in s strokovnimi združenji javnih uslužbencev $v$ državnih organih in upravah lokalnih skupnosti sprejema kodeks etike javnih uslužbencev $v$ državnih organih in upravah lokalnih skupnosti; predlaga komisiji za pritožbe razveljavitev pogodb o zaposlitvi za javne uslužbence.

Pogodba o zaposlitvi in odločba o imenovanju v naziv se razveljavi, če javni uslužbenec ne izpolnjuje pogojev za delovno mesto, za katero je bila pogodba sklenjena, oziroma če pred sklenitvijo pogodbe ni bil izveden predpisan postopek javnega natečaja, čeprav bi moral biti izveden. Pogodba se razveljavi s sklepom. Aneks k pogodbi o zaposlitvi oziroma sklep o premestitvi se razveljavi, če oseba ne izpolnjuje pogojev za delovno mesto, na katero je bila premeščena, oziroma za položaj. Aneks oziroma sklep se razveljavi s sklepom (74. člen ZJU).

Pri uradnikih na položaju se poleg pogojev, predpisanim z zakonom ali podzakonskim predpisom (izobrazba, delovne izkušnje, strokovni izpit ter drugi pogoji) upoštevajo sklopi standardov kot so določene izkušnje, znanja $s$ 
področja poznavanja načel in razvojnih usmeritev delovanja državne uprave, javnih financ, poznavanje delovanja institucij in pravnega reda Evropske unije, upravljanja kadrovskih virov in kakovosti. Prav tako je za vse uradnike na položaju pomembno, da poznajo ureditev in problematiko delovnega področja. Za položaje generalnih direktorjev, predstojnikov organov $v$ sestavi in predstojnikov vladnih služb se zahteva temeljito poznavanje slovenske ureditve in evropskega pravnega reda na področju dela, za položaje generalnih sekretarjev in načelnikov upravnih enot pa se zahteva okvirno poznavanje delovnega področja organa. Poleg standardov pa so določena tudi merila za izbiro primernih kandidatov za posamezen položaj. Merilo za izbiro je stopnja primernosti kandidata pri izpolnjevanju standarda $v$ celoti in posameznega sklopa standarda. Merilo izpolnjevanja zahtev posameznega elementa standarda pa je stopnja ustreznosti (Virant, 2003, str. 20-23).

Uredba o notranji organizaciji, sistemizaciji, delovnih mestih in nazivih $\vee$ organih javne uprave in pravosodnih organih (51. člen) navaja naslednje pogoje za zasedbo delovnega mesta na položaju višjega vodstva: določen naziv, smer izobrazbe oziroma poklicna klasifikacija, funkcionalna in specialna znanja ter posebne sposobnosti, drugi pogoji, če tako določa zakon. Razen naziva, ki je potreben za zasedbo delovnega mesta, so pogoji tudi delovne izkušnje in stopnja izobrazbe. Poleg navedenih pogojev, se lahko pri posameznem delovnem mestu oziroma položaju lahko kot pogoj navedejo tudi znanja, veščine, sposobnosti in lastnosti, ki se upoštevajo med merili pri izbiri javnega uslužbenca.

Funkcionalna, specialna znanja in posebne sposobnosti (glede na vsebino nalog) se kot pogoji izjemoma ne določijo za položaje, za katere standarde strokovne usposobljenosti določi uradniški svet (Uredba o notranji organizaciji, sistemizaciji, delovnih mestih in nazivih $v$ organih javne uprave in pravosodnih organih, 52. člen).

\section{Zaključek}

Delitev delovnih mest na strokovno-tehniška in uradniška zahteva tudi različno obravnavanje $\vee$ postopku zaposlitve delavca na posamezno delovno mesto. Ena od bistvenih razlik je $\vee$ sami objavi, saj je za strokovno-tehniško delovno mesto potrebna javna objava $\vee$ sredstvih javnega obveščanja in objava $\checkmark$ uradnih prostorih Zavoda Republike Slovenije za zaposlovanje, za zaposlitev na uradniškem delovnem mestu pa veljajo pravila javnega natečaja. 


\section{Tatjana Kozjek}

\section{Zaposlovanje javnih uslužbencev}

Zaposlitev $\vee$ upravnih službah pa je mogoča samo na podlagi javnega natečaja, pri čemer je kot merilo primernosti upoštevana kandidatova strokovna usposobljenost. Pri zaposlovanju na najvišje vodstvene položaje $\vee$ državni upravi pa ima pri posebno vlogo uradniški svet, ki določa standarde strokovne usposobljenosti in merila za izbiro. Javni natečaj se objavi $v$ Uradnem listu, dnevnem časopisju in na spletni strani Ministrstva za javno upravo. Potrebno je preverjanje natečajnih pogojev, na podlagi katerih se $v$ izbirnem postopku izbere strokovno najbolj usposobljenega kandidata.

Za sklenitev delovnega razmerja na strokovno-tehničnih delovnih mestih velja pogodbena svoboda, kar pomeni, da ima delodajalec pravico do odločitve, s katerim kandidatom bo sklenil pogodbo o zaposlitvi, upoštevati pa mora zakonske prepovedi glede diskriminacije in kandidatovo izpolnjevanje razpisnih pogojev za opravljanje dela.

Mag. Tatjana Kozjek je od leta 2004 zaposlena na Fakulteti za upravo Univerze v Ljubljani kot asistentka za področje organizacije javnega sektorja. Raziskuje področje organizacije javnega sektorja in upravljanja s človeškimi viri, sodeluje pri pripravi in izvedbi vaj ter seminarjev za javne us/užbence.

\section{Literatura in viri}

- Brejc, M (2002): „Ljudje in organizacija v javni upravi«. II. dopolnjena izdaja. Visoka upravna šola. Ljubljana.

- Kopač, A. (2002): „Pasivna politika zaposlovanja - sistem socialne varnosti za primer brezposelnosti«. Univerza v Ljubljani. Fakulteta za družbene vede, Ljubljana.

- Korpič-Horvat, E. (2008): „Uslužbenska razmerja«. Http://www.pf.unimb.si/datoteke/usluzbenska_razmerja.doc, 18. 11. 2008.

- Korade Purg, š. (2004): "Uradniški svet - izvajanje strokovne usposobljenosti«. XIII. Kadrovske informacije, bilten Kadrovske službe Vlade RS, junij 2004, str. $26-28$.

- Korade Purg, š. (2008): "Postopek sklenitve delovnega razmerja po zakonu o delovnih razmerjih in zakonu o javnih uslužbencih «. Kadrovske informacije, bilten Kadrovske službe Vlade RS, april, 2008, str. 28-35. Http://www.mju.gov.si/si/delovna_razmerja_in_ stipendiranje/kadrovske_informacije/, 15. 06. 2008.

- Koželj, B. (2004): „Postopek za zasedbo prostega delovnega mesta «. XII. Kadrovske informacije, bilten Kadrovske službe Vlade RS, februar 2004, str. 28-31. 
- Ministrstvo za javno upravo. "Za javne uslužbence«. Http://www.mju.gov.si/si/ prijazna_in_ucinkovita_uprava/za_javne_usluzbence/, 20. 10. 2008.

- Poslovnik uradniškega sveta, št. 906-5/2003 z dne 21. 02. 2005 in 23. 01. 2007. Http://www.mju.gov.si/fileadmin/mju.gov.si/pageuploads/mju_dokumenti/doc/Uradni_ki _svet_01.doc, 15. 06. 2008.

- Ramšak Pešec, M. (2007): „Novosti v postopkih pri zaposlovanju v državni upravi. Nadaljnji korak za uporabnikom prijazno in učinkovito državno upravo«. HRM, februar, 2007, str. 10-13.

- Sajevec Plavčak, N. (2003): "Ustanovitev Uradniškega sveta«. X. Kadrovske informacije, bilten Kadrovske službe Vlade RS, marec 2003, str. 22-24.

- Uredba o notranji organizaciji, sistemizaciji, delovnih mestih in nazivih v organih javne uprave in pravosodnih organih. Uradni list RS, št. 58/2003, 81/2003, 109/2003, 43/2004, 58/2004-popravki, 138/2004, 35/2005, 60/2005, 75/2005, 112/2005, 49/2006, 140/2006, 9/2007, 101/2007, 33/2008, 66/2008, 88/2008.

- Uredba o postopku za zasedbo delovnega mesta v organih državne uprave in pravosodnih organih. Uradni list RS, št. 22/2004, 57/2005, 93/2005, 10/2006, 139/2006.

- Virant, G. (2003): „Predlogi za standarde strokovne usposobljenosti in meril za izbiro "top menedžmenta $v$ državni upravi«. XI. Kadrovske informacije, bilten Kadrovske službe Vlade RS. Julij 2003, str. 20-24.

- Vodovnik, Z. (2004): „Poglavja iz delovnega in socialnega prava». Fakulteta za upravo, Ljubljana.

- Zakon o javnih uslužbencih (ZJU). Uradni list RS, št. 56/2002, 110/2002-ZDT-B, 02/2004ZDSS-1, 10/2004-popravek, 23/2005, 35/2005-UPB1, 62/2005 Odl. US: U-I 294/04-15, 113/2005, 21/2006 Odl. US: U-I 343/04-11, 23/2006 SkI. US: UI 341/05-10, 32/2006UPB2, 32/2006 UPB2, 62/2006 Skl. US: U-I-227/06-17, 131/2006 Odl. US: U-I-227/06-27, 11/2007 Skl. US: U-I-224/05-14, 33/2007, 63/2007-UPB3, 65/2008, 69/2008 ZTFI-A, 69/2008 ZZav-E. 
Tatjana Kozjek

Zaposlovanje javnih uslužbencev

\section{SUMMARY}

\section{RECRUITMENT OF CIVIL SERVANTS}

The Law on civil servants states that civil servants are individuals who are employed on the basis of a labour contract in the public sector. It also states a distinction between civil officials and other civil servants.

Article 51 of the Regulation on internal organisation, systemisation, workplace and titles in the public administration and administration of justice states that professional-technical workplaces are those where servants perform tasks, belonging to the working area of national or local community bodies i.e., tasks which are founded on the basis of a legal entity, with a professional-technical content (other accompanying tasks), but which do not include the official tasks.

The regulation also states that officials perform public tasks and may occupy workplaces in finance, accounting, human resources, legal departments and information technology, in head offices and public relations departments. The official workplaces of civil servants performing demanding accompanying tasks, which are crucial for the execution of the body's duties, demand occupant's thorough knowledge of the bodies' duties and at least high professional education. Regardless of the necessary level of education, the official workplaces include places in the Slovenian intelligence-security agency, the security intelligence office of the Ministry of defence and Police, the workplaces for accompanying tasks directly linked with operational police and intelligence-security tasks.

Article 80 of the law on Civil servants states that an official position is official, if it contains the tasks of management (planning, organising, leading and controlling) and the most demanding expert tasks or replacement tasks and direct assistance to officials in the position of director general or secretary general in the Ministries or of a director of a body affiliated to the Ministry and head of a government office (deputies).

The particularities of civil servant's working relations are subject of the Law on Civil servants, but matters concerning working relations and the rights and duties of public servants are also subject to working relations regulations and the collective labour agreement. The general labour law therefore applies to all matters, which do not fall under the jurisdiction of Law on civil servants or sector-specific law. In connection with employment relationships, civil servants have to be warned about the fact 
that the other contracting authority is the state or the municipality, as the majority of the law applies to civil servants in public bodies or local community administrations. This fact is highly relevant, since in both cases, the contracting parties are legal persons executing authority.

Article 78 of the Law on civil servants states that official work posts in the state administration bodies and local community administration are classified on the basis of a government regulation. In other bodies the classification is laid down by a general act. Official work posts can be classified by a collective labour agreement. The professional technical posts in all bodies are classified by a government regulation. In addition, they could be classified by a collective labour agreement. The professional-technical (administrative) posts are classified according to the title of the professional-technical post, the list of tasks to be performed on a particular professional-technical post, the required amount of work experience, level of education, specified by tariff classification. There are certain general conditions prescribed by labour law regulations, the level and field of studies or professional qualifications and work experience, for taking the position of individual professional-technical posts.

The law on employment relationships states that employment relationship for professional-technical posts is concluded by an employment contract founded freedom of agreement. This means that the employer has the right to choose the candidate with whom the employment relationship will be made i.e. employment contract, by taking into account the candidate's qualifications for the post. The necessity to fulfil the requirements of the position present during the conclusion of the contract is mutual and is binding for the employer as well as the employee. An employee, who is to enter into a working contract must fulfil the necessary requirements, and the employer is obliged to establish employment relationship with a candidate who is fully fulfilling the requirements. The requirements for the position can be laid down in a law, a collective labour agreement or set by the employer in a general act. All the free work posts and the conditions for their fulfilment need to be published officially. The deadline for application, a minimum of five days, also needs to be set.

The law on civil servants and Article 122 of the Constitution of the Republic of Slovenia stipulate that the rules of public tender also apply to fulfilment of official work positions. Employment in administrative bodies should be advertised on the basis of public call, with the exception of cases otherwise stated by the law. The procedure, defined in detail by the 
Law on civil servants, which guarantees that the most appropriate candidate is selected on the basis level of his or her competence to take the position in the most efficient and successful way.

In addition to conditions set in the law or the regulation (education and training, work experience, professional exam and other conditions), a set of standards determines candidate's level of experience, the knowledge of the principles and development guidelines of the public administration, public finance and human resource management, quality also relates to officials in positions. Candidates also have to possess a thorough knowledge of the layout and issues related to their field of work. Thorough knowledge of functioning of the Slovenian administration and the European acquis in their field of work is required in all positions of Director general, head of bodies affiliated to Ministries and head of government offices. Indicative knowledge of the body's work field is required of general secretaries and heads of administrative units. The requirements for selection of the most appropriate candidate for individual positions are defined in addition to standards. Level of appropriateness of the candidate for full fulfilment of standard requirement as well as individual sets of standards are criteria for selection. 